\title{
Head and Leaf Fungicide Deposit on Winter Wheat, Deoxynivalenol Content and Yield Parameters As Affected by Different Nozzle Types
}

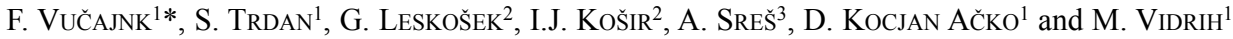 \\ ${ }^{1}$ University of Ljubljana, Biotechnical Faculty, Department of Agronomy, Chair of Phytomedicine, \\ Agricultural Engineering, Crop Production, Pasture and Grassland Management. \\ Jamnikarjeva 101, SI - 1111 Ljubljana, Slovenia \\ ${ }^{2}$ Slovenian Institute of Hop Research and Brewing, Cesta Žalskega tabora 2, SI - 3310 Žalec, Slovenia \\ ${ }^{3}$ Bayer d.o.o., Bayer CropScience, Bravničarjeva 13, SI - 1000 Ljubljana, Slovenia
}

(Received 17 March 2017; Accepted 31 August 2017; Communicated by Á. Mesterházy)

\begin{abstract}
In 2014 and 2015, we studied the effect of fungicide spraying with 11 different nozzles on the quality and quantity of head and leaf fungicide deposit, the percentage of Fusarium head blight (FHB) incidence, FHB index, the DON content, yield and grain quality parameters. The best quality and quantity of fungicide deposit on the front and rear head sides was achieved with the TeeJet Turbo FloodJet TF VP2 nozzle (FLOOD) and the Albuz AVI-TWIN 110-03 nozzle (AVI). In comparison with the majority of treatments, the FHB incidence and the FHB index was the highest on the unsprayed control. The FHB index was higher using the Lechler IDK 120-03 nozzle (IDK) than with the other nozzle types. In all the treatments, the DON content in the grain was less than $50 \mu \mathrm{g} / \mathrm{kg}$. At this very low level of infection this is not surprising. The grain yield was the smallest on the unsprayed control. Better fungicide coverage of wheat heads with the FLOOD and AVI nozzles did not result in a statistically higher yield or better grain quality parameters. Negative correlations were confirmed between yield and variables as DON content, FHB incidence and FHB index and also between falling number and variables as fungicide coverage, FHB incidence and FHB index. Positive correlations were determined between DON content and FHB incidence, between hectolitre weight and variables as spray deposit and coverage and between protein content and variables as spray deposit and coverage.
\end{abstract}

Keywords: nozzles, coverage value, deposit, Fusarium head blight, yield, grain quality

\section{Introduction}

Fusarium head blight (FHB) of wheat can be caused by various fungi of the genus Fusarium. Hollingsworth et al. (2006) determined that wheat fungicide control against FHB increased the wheat yield by $8.3 \%$; furthermore, the thousand grain weight was $17.4 \%$ higher than without FHB control. In a three-year trial in relation to FHB control with a preparation based on a metconazole active ingredient, the grain yield on the sprayed treat-

*Corresponding author; E-mail: filip.vucajnk@bf.uni-lj.si; Phone: +386 13203131; Fax: +386 14231088 
ments was on average higher by $26 \%$, the hectolitre weight by $2 \%$ and the thousand grain weight by $6 \%$ (Blandino et al. 2011). Ransom and McMullen (2008) determined that, in comparison to the unsprayed control, the yield increased by 5-11\% with weaker FHB infections or by $27-44 \%$ with stronger FHB infections after the wheat had been sprayed with a fungicide. Stronger FHB infections can halve the wheat grain yield (Mesterházy et al. 2003). The protein content and fat content in infected grains increased by $6 \%$ and $13 \%$, respectively. The increased protein content was predominantly due to the development of Fusarium sp. fungi mycelium, which contains $42 \%$ of crude protein (Breiteneder and Radauer 2004).

Until the end of the $20^{\text {th }}$ century, it was possible to achieve an approximately $20 \%$ coverage of the front head side and an approximately $10 \%$ coverage of the rear head side with the best techniques available (Halley et al. 1999). Parkin et al. (2006), however, claimed that the coverage and efficiency of FHB control performed with single flat fan nozzles can be improved by moving the spray jet slightly backwards in relation to the driving direction or by using nozzles with a double flat fan. Mesterházy et al. (2011) and Lechoczki-Krsjak et al. (2008) determined 60\% efficiency of FHB control with 9 fungicides, while using AIC TeeJet and TeeJet XR nozzles. Turbo TeeJet Duo nozzles and Turbo FloodJet ${ }^{\circledR}$ nozzles had $70 \%$ and $80 \%$ efficiency in FHB control, respectively. Vajs et al. (2008) achieved the best wheat head coverage with Albuz API 110-03 nozzles (VMD $170 \mu \mathrm{m}$ ) and the poorest coverage with air-injector Lechler IDK 120-03 nozzles. By using Agrotop DF 110-015 double flat fan air-injector nozzles with forward- and backward-angled spray jet of $30^{\circ}$, Marshal et al. (2000) managed to improve the wheat head coverage and efficiency of FHB control considerably. Mesterházy et al. (2011) reached $12 \%$ coverage of wheat heads with the use of TeeJet XR nozzles and $37 \%$ fungicide coverage of wheat heads with the use of Turbo FloodJet deflector nozzles. Spraying with a Turbo FloodJet nozzle resulted in more efficient FHB control and subsequently smaller DON contamination of wheat grains in comparison to the use of TeeJet XR nozzles.

The aim of our trial was to evaluate the effect of fungicide spraying with different nozzles on wheat head and leaf coverage, on yield and grain quality, on the percentage of FHB-infected heads and on DON content.

\section{Materials and Methods}

\section{Fungicide treatments}

Between 2013 and 2015, a field trial was performed on the lab field of the Biotechnical Faculty, University of Ljubljana, Slovenia (46 03' N, $1431^{\prime}$ E). Its base consisted of random blocks with 4 repetitions. The area of each trial plot was $135 \mathrm{~m}^{2}(30 \mathrm{~m} \times 4.5 \mathrm{~m})$. Eleven different nozzle types were used for spraying wheat heads with a fungicide based on protioconazole and tebuconazole active ingredients (Prosaro) (Table 1).

The spraying pressure was 5.0 bars, the spraying speed $6.0 \mathrm{~km} / \mathrm{h}$ and the water consumption 300 1/ha. Water consumption with the FLOOD nozzle was 350 1/ha, the pressure 
Table 1. Nozzle types used in the trial and their technical specifications

\begin{tabular}{|l|l|c|c|c|}
\hline \multicolumn{1}{|c|}{ Nozzle type } & \multicolumn{1}{|c|}{ Description } & $\begin{array}{c}\text { Spray angle } \\
\left({ }^{\circ}\right)\end{array}$ & VMD $(\mu \mathrm{m})$ & $\begin{array}{c}\text { Spray angle to the } \\
\text { vertical line }\left(^{\circ}\right)\end{array}$ \\
\hline Lechler ST 110-03 (ST) & Flat fan & 110 & $125-250$ & 0 \\
\hline Lechler IDK 120-03 (IDK) & Injector flat fan & 120 & $350-450$ & 0 \\
\hline Lechler ID 120-03 (ID) & Injector flat fan & 120 & $350-450$ & 0 \\
\hline TeeJet TT11003 (TT) & Flat fan & 110 & $175-250$ & 15 (forward) \\
\hline TeeJet TTJ60-11003 (TTJ) & Double flat fan & $2 \times 110$ & $250-375$ & $30 / 30$ \\
\hline $\begin{array}{l}\text { Albuz AVI TWIN 110-03 } \\
\text { (AVI) }\end{array}$ & Injector double flat fan & $2 \times 110$ & $350-400$ & $10 / 50$ \\
\hline $\begin{array}{l}\text { Agrotop TurboDrop } \\
\text { HiSpeed 110-03 (SPEED) }\end{array}$ & Injector double flat fan & $2 \times 110$ & $350-400$ & $10 / 50$ \\
\hline TeeJet AI 3070-03 VP (AI) & Injector double flat fan & $2 \times 110$ & $375-450$ & $30 / 70$ \\
\hline Lechler TR 80-03 (TR) & Standard hollow cone & 80 & $125-250$ & $40 / 40$ \\
\hline $\begin{array}{l}\text { Agrotop TurboDrop } \\
\text { HC 80-03 (TD) }\end{array}$ & Injector hollow cone & 80 & $350-400$ & $40 / 40$ \\
\hline $\begin{array}{l}\text { TeeJet Turbo FloodJet } \\
\text { TF-VP 2 (FLOOD) }\end{array}$ & Wide angle flat fan & $140-150$ & $>450$ & 75 alternating \\
\hline
\end{tabular}

and the spraying speed the same as with the other nozzles. FLOOD nozzles were alternately attached to the spray boom. The first had a forward-angled spray jet, the one next to it a backward-angled spray jet in relation to the driving direction. Spraying was performed with an AGS $600 \mathrm{EN}$ tractor-mounted sprayer and $9 \mathrm{~m}$ wide spray boom.

\section{Plant material}

Before spraying, 3 plants were randomly chosen on each plot and water sensitive paper (WSP) was attached to them. On each plant, the WSPs were placed on the front and rear head side, on the leaves from the top towards the bottom part of the plant and on the ground. This allowed a qualitative evaluation of the fungicide deposit on the whole plant. For a quantitative analysis of the deposit, a fluorescent UV dye (Helios $500 \mathrm{SC}$ ) was used at an application rate of $3 \mathrm{ml}$ per $100 \mathrm{~L}$ of water. All the technical parameters of spraying with a tracer were the same as in the trial involving the WSPs. Before spraying, filter papers of the same dimensions as the WSPs were attached to the front and the rear head sides. Spraying was performed during the BBCH 61. The wheat heads were sprayed on $28^{\text {th }}$ May 2014 and on $25^{\text {th }}$ May 2015. In both years, the wind speed during spraying ranged between 0.5 and $1.0 \mathrm{~m} / \mathrm{s}$ and the air humidity was approximately $70 \%$. In 2014 and 2015 , the air temperature during spraying was $15.0{ }^{\circ} \mathrm{C}$ and $16.2{ }^{\circ} \mathrm{C}$, respectively. The average temperature from the heading until the end of June was $19.6{ }^{\circ} \mathrm{C}$ in 2014 and $19.2^{\circ} \mathrm{C}$ in 2015 . In 2014 it was $160 \mathrm{~mm}$ of precipitation in that time and in 2015 it was $210 \mathrm{~mm}$ of precipitation. 
The more FHB-sensitive winter wheat cultivar Vulcanus, from the Saatbau Linz plant breeder, Austria, was used in the trial (Ages 2013). In both trial years, grain maize had been the previous crop in the field. The trial field was ploughed with a reversible plough and cultivated with a rotary harrow before seeding of winter wheat each year.

\section{Data collection}

The droplet impression measurements on the WSPs were performed at the Slovenian Institute of Hop Research and Brewing in Žalec. The Optomax V. Image Analyser measuring system (Optomax) was used to capture and analyse the images. To determine the concentration of the tracer, we used a liquid chromatography instrument equipped with a fluorescent detector (HPLC-FLD).

Approximately three weeks after spraying the wheat heads, we counted the number of FHB-infected heads per $0.25 \mathrm{~m}^{2}$ and the total number of heads on each plot. Based on these data, we calculated the percentage of FHB-infected heads per $0.25 \mathrm{~m}^{2}$ (FHB incidence). On each plot at 10 random places, we evaluated the FHB-infected heads on a 1-9 scale (Miedaner 2012). On each of them, 3 plants were selected and accurately examined (EPPO 1997). Number 1 means no infected wheat head area, while 9 means that more than $95 \%$ of the wheat head area was infected. From these data FHB index was calculated. Before harvest, 300 wheat heads were collected from each trial plot. The grains were separated from the samples with a Wintersteiger seed tresher SeedBoy at low wind speeds $(<1.5 \mathrm{~m} / \mathrm{s})$ and all the grain from heads was collected. These grain were then analysed on DON content. These grain samples were analysed for deoxynivalenol mycotoxin (DON) content according to the Rosa ${ }^{\circledR} D O N$ Quantitative Flow Chart Test enzymatic method. Each trial plot was harvested with a Wintersteiger plot harvester with a $1.5 \mathrm{~m}$ working width. The wind speed of cleaning fan on the combine harvester was adjusted to $2 / 3$ of maximum wind speed. After harvest, the grain yield at $14 \%$ moisture was calculated for all the grain samples. Analysis of grain quality was performed by the Bureau Veritas company according to standard procedures. The thousand grain weight, the hectolitre weight, the protein content in the grains, the falling number and the sedimentation value were measured.

\section{Statistics}

The measurement data were saved into a Microsoft Excel file. Further statistical analyses were performed with Statgraphics Centurion XVI software. We first examined the homogeneity of variance. Data with percentage values were transformed with the use of the 'arc sin (sqrt/100)' function. Analysis of variance and the Duncan Multiple Range Test $(p<0.05)$ were performed. At the end correlation matrix was calculated for different variables. The data are presented as two years mean. 


\section{Results}

Coverage value, tracer deposit, DON content, FHB incidence and FHB index

The smallest coverage value on the front head side was achieved with the ID nozzle (7.3\%), followed by IDK, SPEED and TT nozzles. The best spray mixture coverage value on the front head side was reached with the FLOOD nozzle $(35.9 \%)$; this value was slightly lower with the AVI nozzle (Tables 2, S1 and S2). The best coverage value on the rear head side was achieved with the AVI nozzle (23.9\%), followed by the SPEED nozzle. The smallest coverage value was achieved with the ST nozzle $(9.3 \%)$, followed by the TR, IDK, AI and ID nozzles. On the flag leaf, the use of the ST nozzle resulted in a higher coverage value (47.9\%) than the use of other nozzles (29.7-38.8\%). Also on the second leaf, the best and the smallest coverage value were achieved with the ST nozzle $(33.8 \%)$ and the FLOOD nozzle (19.5\%). On the third leaf, the use of the ST nozzle resulted in a higher coverage value $(32.6 \%)$ than the use of other nozzles. On the fourth leaf, the best and the smallest coverage values were reached with the TR nozzle $(25.0 \%)$ and the FLOOD nozzle (10.6\%). On the ground, the use of ID, IDK and TTJ nozzles resulted in better coverage values than the use of the TD nozzle.

Table 2. Coverage value after spraying against FHB using different nozzle types in the fungicid tests with Prosaro against FHB in wheat, 2014-2015 (\%). The data represent two years mean

\begin{tabular}{|l|c|c|c|c|c|c|c|}
\hline \multirow{2}{*}{$\begin{array}{c}\text { Nozzle } \\
\text { type }\end{array}$} & \multicolumn{3}{|c|}{ Head } & \multicolumn{5}{c|}{ Leaf } & Ground \\
\cline { 2 - 8 } & Front & Rear & $1^{\text {st }}$ & $2^{\text {nd }}$ & $3^{\text {rd }}$ & $4^{\text {th }}$ & $5^{\text {th }}$ \\
\hline AI & $17.5 \mathrm{cde}^{1}$ & $11.6 \mathrm{abc}$ & $36.5 \mathrm{a}$ & $29.8 \mathrm{bcd}$ & $19.7 \mathrm{abc}$ & $16.1 \mathrm{abc}$ & $22.8 \mathrm{ab}$ \\
\hline AVI & $22.0 \mathrm{e}$ & $23.9 \mathrm{f}$ & $33.9 \mathrm{ab}$ & $26.8 \mathrm{abcd}$ & $18.7 \mathrm{ab}$ & $21.7 \mathrm{bc}$ & $27.1 \mathrm{ab}$ \\
\hline FLOOD & $35.9 \mathrm{f}$ & $17.2 \mathrm{cde}$ & $38.7 \mathrm{ab}$ & $19.5 \mathrm{a}$ & $20.2 \mathrm{abc}$ & $10.6 \mathrm{a}$ & $28.6 \mathrm{ab}$ \\
\hline ID & $7.3 \mathrm{a}$ & $13.3 \mathrm{abcd}$ & $38.1 \mathrm{ab}$ & $23.4 \mathrm{abc}$ & $17.6 \mathrm{ab}$ & $19.7 \mathrm{abc}$ & $33.0 \mathrm{~b}$ \\
\hline IDK & $11.4 \mathrm{abc}$ & $11.0 \mathrm{ab}$ & $38.8 \mathrm{ab}$ & $25.1 \mathrm{abcd}$ & $15.7 \mathrm{ab}$ & $20.5 \mathrm{bc}$ & $32.4 \mathrm{~b}$ \\
\hline SPEED & $11.3 \mathrm{ab}$ & $22.9 \mathrm{ef}$ & $29.7 \mathrm{a}$ & $22.4 \mathrm{abc}$ & $14.5 \mathrm{ab}$ & $14.6 \mathrm{ab}$ & $25.0 \mathrm{ab}$ \\
\hline ST & $14.4 \mathrm{bcd}$ & $9.3 \mathrm{a}$ & $47.9 \mathrm{~b}$ & $33.8 \mathrm{~d}$ & $32.6 \mathrm{~d}$ & $23.5 \mathrm{bc}$ & $31.0 \mathrm{ab}$ \\
\hline TD & $18.5 \mathrm{de}$ & $18.5 \mathrm{def}$ & $30.4 \mathrm{a}$ & $22.6 \mathrm{abc}$ & $13.0 \mathrm{a}$ & $15.0 \mathrm{ab}$ & $20.9 \mathrm{a}$ \\
\hline TR & $17.3 \mathrm{cde}$ & $11.0 \mathrm{ab}$ & $36.4 \mathrm{ab}$ & $30.6 \mathrm{~cd}$ & $26.9 \mathrm{~cd}$ & $25.0 \mathrm{c}$ & $25.3 \mathrm{ab}$ \\
\hline TT & $11.6 \mathrm{abc}$ & $19.1 \mathrm{def}$ & $36.6 \mathrm{ab}$ & $21.3 \mathrm{ab}$ & $21.8 \mathrm{bc}$ & $20.1 \mathrm{bc}$ & $28.6 \mathrm{ab}$ \\
\hline TTJ & $18.9 \mathrm{de}$ & $15.4 \mathrm{bcd}$ & $36.2 \mathrm{ab}$ & $24.8 \mathrm{abcd}$ & $17.9 \mathrm{ab}$ & $19.2 \mathrm{abc}$ & $32.5 \mathrm{~b}$ \\
\hline
\end{tabular}

${ }^{1}$ The means within each column followed by different letters are significantly different at the 0.05 level according to Duncan's test.

We compared the performance of various nozzles in relation to the coverage value and the quantity of deposit on the entire wheat head in both trial years (Tables 3, S3 and S4). The coverage value on the entire wheat head proved to be higher with the FLOOD nozzle $(26.5 \%)$ than with the other nozzles, with the exception of the AVI nozzle $(22.9 \%)$. The 
Table 3. Tracer deposits $(\mu \mathrm{g})$, coverage values $(\%)$, DON content, FHB incidence and FHB index on wheat heads after spraying against FHB using different nozzle types in the fungicide tests with Prosaro against FHB in wheat, 2014-2015. The data represent two years mean

\begin{tabular}{|l|c|c|c|c|c|}
\hline Nozzle type & $\begin{array}{c}\text { Tracer } \\
\text { deposit }(\mu \mathrm{g}) \\
(\text { front }+ \text { rear) }\end{array}$ & $\begin{array}{c}\text { Coverage } \\
\text { value (\%) } \\
(\text { front }+ \text { rear) }\end{array}$ & $\begin{array}{c}\text { DON } \\
\text { content }(\mu \mathrm{g} / \mathrm{kg})\end{array}$ & $\begin{array}{c}\text { FHB } \\
\text { incidence (\%) }\end{array}$ & $\begin{array}{c}\text { FHB } \\
\text { index (\%) }\end{array}$ \\
\hline AI & $0.412 \mathrm{bc}^{1}$ & $14.6 \mathrm{abc}$ & $0.0 \mathrm{a}$ & $1.3 \mathrm{a}$ & $0.2 \mathrm{a}$ \\
\hline AVI & $0.479 \mathrm{c}$ & $22.9 \mathrm{de}$ & $6.25 \mathrm{a}$ & $1.3 \mathrm{a}$ & $0.2 \mathrm{a}$ \\
\hline FLOOD & $0.470 \mathrm{c}$ & $26.5 \mathrm{e}$ & $18.75 \mathrm{a}$ & $1.3 \mathrm{a}$ & $0.2 \mathrm{a}$ \\
\hline ID & $0.085 \mathrm{a}$ & $10.3 \mathrm{a}$ & $0.0 \mathrm{a}$ & $3.6 \mathrm{ab}$ & $0.6 \mathrm{a}$ \\
\hline IDK & $0.120 \mathrm{a}$ & $11.2 \mathrm{ab}$ & $0.0 \mathrm{a}$ & $6.0 \mathrm{ab}$ & $1.3 \mathrm{~b}$ \\
\hline Control & $-*$ & $-*$ & $25.0 \mathrm{a}$ & $12.4 \mathrm{c}$ & $3.8 \mathrm{c}$ \\
\hline SPEED & $0.231 \mathrm{ab}$ & $17.1 \mathrm{c}$ & $6.25 \mathrm{a}$ & $2.4 \mathrm{ab}$ & $0.3 \mathrm{a}$ \\
\hline ST & $0.139 \mathrm{a}$ & $11.9 \mathrm{ab}$ & $0.0 \mathrm{a}$ & $3.4 \mathrm{ab}$ & $0.6 \mathrm{a}$ \\
\hline TD & $0.246 \mathrm{ab}$ & $18.5 \mathrm{~cd}$ & $0.0 \mathrm{a}$ & $3.9 \mathrm{ab}$ & $0.7 \mathrm{a}$ \\
\hline TR & $0.141 \mathrm{a}$ & $14.1 \mathrm{abc}$ & $0.0 \mathrm{a}$ & $3.8 \mathrm{ab}$ & $0.6 \mathrm{a}$ \\
\hline TT & $0.158 \mathrm{a}$ & $15.3 \mathrm{bc}$ & $6.25 \mathrm{a}$ & $4.4 \mathrm{ab}$ & $0.7 \mathrm{a}$ \\
\hline TTJ & $0.247 \mathrm{ab}$ & $17.1 \mathrm{c}$ & $0.0 \mathrm{a}$ & $3.7 \mathrm{ab}$ & $0.7 \mathrm{a}$ \\
\hline
\end{tabular}

${ }^{1}$ The means within each column followed by different letters are significantly different at the 0.05 level according to Duncan's test. *Unsprayed control.

use of the AVI nozzle $(0.479 \mu \mathrm{g})$ and the FLOOD nozzle $(0.470 \mu \mathrm{g})$ resulted in a larger quantity of the deposit on the entire wheat head than the use of other nozzles, with the exception of the AI nozzle, with a $0.411 \mu \mathrm{g}$ deposit on the entire wheat head. The lowest deposit was determined by nozzles ID, IDK, ST, TR and TT.

No significant differences in DON content were found between different nozzle types. In both trial years, the DON content was very low, between 0 and $50 \mu \mathrm{g} / \mathrm{kg}$ (Tables 3 and S5). When taking into account the two-year average, the unsprayed control had a higher FHB incidence in comparison with the treatments involving different nozzles. The highest FHB index was determined on the unsprayed control. With the use of AI, AVI, FLOOD, ID, SPEED, ST, TD, TR, TT and TTJ nozzles lower FHB index was determined as with the use of IDK nozzle.

\section{Yield and its parameters}

The use of IDK and TD nozzle resulted in a higher yield at $14 \%$ moisture in comparison to other treatments (Table 4). No statistically significant differences were found in the thousand grain weight among the different treatments (42.2-44.7 g). By hectolitre weight (HW), falling number (FN), sedimentation (SED) and protein content (PC) no significant differences appeared between treatments (Tables 4, S6 and S7). Hectolitre weight was high by this cultivar and it ranged from 81.0 to $82.9 \mathrm{~kg} / 100 \mathrm{~L}$. Falling num- 
Table 4. Yield (t/ha), thousand grain weight (g), hectolitre weight $(\mathrm{kg} / 100 \mathrm{~L})$, falling number (s), sedimentation $(\mathrm{g})$ and protein content $(\%)$ in the fungicid tests with Prosaro against FHB in wheat, 2014-2015. The data represent two years mean

\begin{tabular}{|l|c|c|c|c|c|c|}
\hline $\begin{array}{c}\text { Nozzle } \\
\text { type }\end{array}$ & Yield (t/ha) & TGW (g) & $\begin{array}{c}\text { HW } \\
(\mathrm{kg} / 100 \mathrm{~L})\end{array}$ & FN (s) & SED (g) & PC (\%) \\
\hline AI & $7.1 \mathrm{ab}^{1}$ & $42.2 \mathrm{a}$ & $82.2 \mathrm{a}$ & $339 \mathrm{a}$ & $54 \mathrm{a}$ & $14.0 \mathrm{a}$ \\
\hline AVI & $7.2 \mathrm{ab}$ & $42.8 \mathrm{a}$ & $81.8 \mathrm{a}$ & $339 \mathrm{a}$ & $46 \mathrm{a}$ & $13.5 \mathrm{a}$ \\
\hline FLOOD & $6.8 \mathrm{ab}$ & $43.4 \mathrm{a}$ & $81.6 \mathrm{a}$ & $316 \mathrm{a}$ & $54 \mathrm{a}$ & $14.4 \mathrm{a}$ \\
\hline ID & $7.1 \mathrm{ab}$ & $43.2 \mathrm{a}$ & $81.2 \mathrm{a}$ & $316 \mathrm{a}$ & $48 \mathrm{a}$ & $13.7 \mathrm{a}$ \\
\hline IDK & $7.9 \mathrm{~b}$ & $43.4 \mathrm{a}$ & $82.9 \mathrm{a}$ & $347 \mathrm{a}$ & $47 \mathrm{a}$ & $13.5 \mathrm{a}$ \\
\hline control & $6.1 \mathrm{a}$ & $42.7 \mathrm{a}$ & $81.0 \mathrm{a}$ & $304 \mathrm{a}$ & $48 \mathrm{a}$ & $13.7 \mathrm{a}$ \\
\hline SPEED & $6.9 \mathrm{ab}$ & $44.7 \mathrm{a}$ & $82.5 \mathrm{a}$ & $319 \mathrm{a}$ & $52 \mathrm{a}$ & $14.0 \mathrm{a}$ \\
\hline ST & $6.8 \mathrm{ab}$ & $44.6 \mathrm{a}$ & $81.5 \mathrm{a}$ & $309 \mathrm{a}$ & $49 \mathrm{a}$ & $13.8 \mathrm{a}$ \\
\hline TD & $7.9 \mathrm{~b}$ & $43.1 \mathrm{a}$ & $82.0 \mathrm{a}$ & $335 \mathrm{a}$ & $56 \mathrm{a}$ & $14.4 \mathrm{a}$ \\
\hline TR & $6.8 \mathrm{ab}$ & $43.7 \mathrm{a}$ & $82.1 \mathrm{a}$ & $293 \mathrm{a}$ & $48 \mathrm{a}$ & $13.6 \mathrm{a}$ \\
\hline TT & $7.2 \mathrm{ab}$ & $42.4 \mathrm{a}$ & $81.5 \mathrm{a}$ & $333 \mathrm{a}$ & $56 \mathrm{a}$ & $14.7 \mathrm{a}$ \\
\hline TTJ & $7.3 \mathrm{ab}$ & $42.9 \mathrm{a}$ & $82.0 \mathrm{a}$ & $306 \mathrm{a}$ & $50 \mathrm{a}$ & $13.9 \mathrm{a}$ \\
\hline
\end{tabular}

${ }^{1}$ The means within each column followed by different letters are significantly different at the 0.05 level according to Duncan's test.

ber ranged from 293-347 s, sedimentation value from 46-56 g and protein content from $13.5-14.7 \%$.

\section{Correlation matrix}

Significant correlation $(p<0.05)$ was found between yield and HW, yield and PC, yield and FN, yield and SED, yield and DON content, yield and FHB index (Table 5). 96 pairs of data were used to compute each coefficient. Negative correlation coefficients appeared between yield and HW, yield and PC, yield and DON content, yield and FHB index. Between HW and PC, HW and FN, HW and deposit, HW and coverage of wheat heads and between HW and FHB index statistically significant correlations were determined. Regarding protein content significant correlation was found between $\mathrm{PC}$ and $\mathrm{FN}, \mathrm{PC}$ and SED, PC and deposit, PC and coverage of wheat heads and between PC and DON content. Significant correlation was also found between FN and SED, FN and coverage, FN and FHB incidence and between FN and FHB index. There was also significant positive correlation between deposit and coverage, between DON content and FHB incidence and negative correlation between TGW and FHB incidence. 


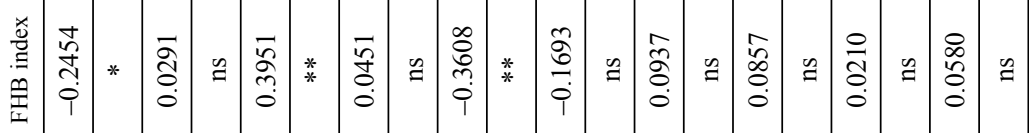

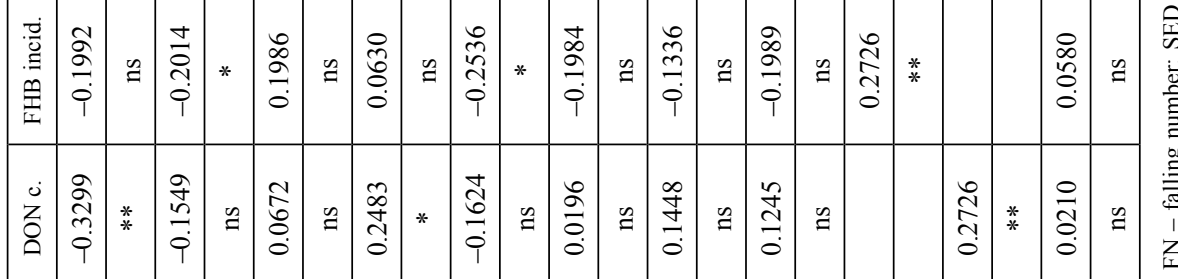

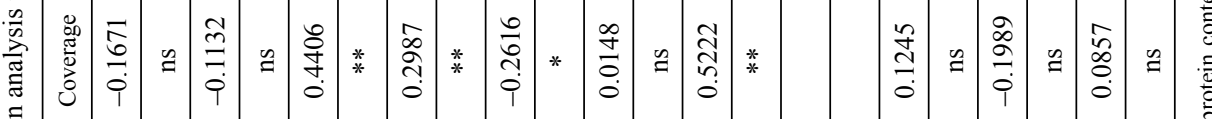

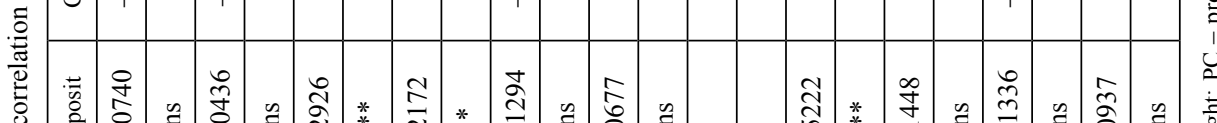
Ð

$\frac{0}{0}$

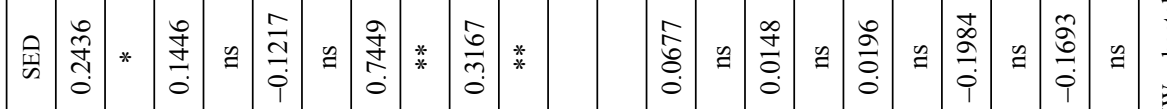

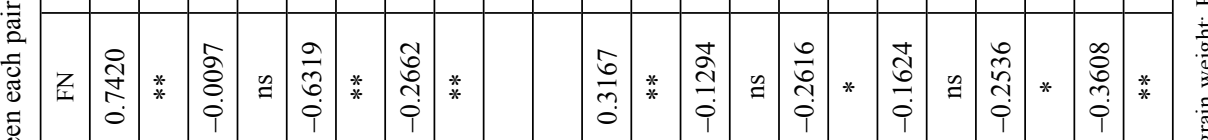

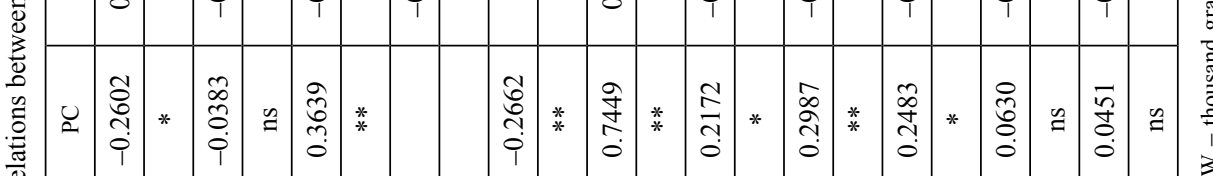

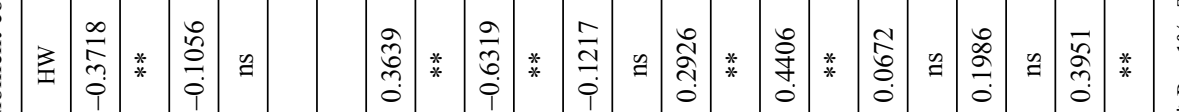

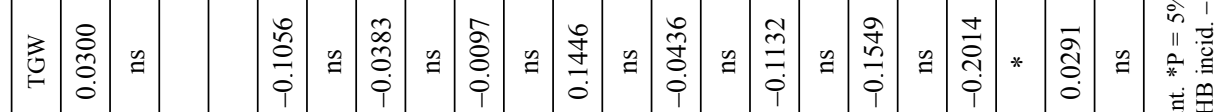

\begin{tabular}{|c|c|c|c|c|c|c|c|c|c|c|c|c|c|c|c|c|c|c|c|c|c|}
\hline$F$ & 0 & & & $\dot{9}$ & & $\dot{\varphi}$ & & $\dot{\varphi}$ & & $\dot{0}$ & & $\dot{\varphi}$ & & $\dot{\varphi}$ & & $\dot{\varphi}$ & & $\dot{\varphi}$ & & 0 & \\
\hline$\frac{\overrightarrow{0}}{2}$ & & $\mid \begin{array}{l}0 \\
0 \\
0 \\
0 \\
0 \\
0\end{array}$ & $\stackrel{g}{g}$ & 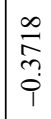 & * & 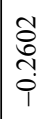 & $*$ & 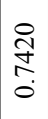 & * & 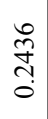 & $*$ & $\begin{array}{l}\stackrel{0}{+} \\
\text { O } \\
\stackrel{1}{1}\end{array}$ & $\stackrel{a}{a}$ & $\begin{array}{c}\vec{\sigma} \\
\stackrel{0}{9}\end{array}$ & $\stackrel{n}{=}$ & $\begin{array}{l}2 \\
\stackrel{2}{2} \\
\tilde{?} \\
0\end{array}$ & * & $\frac{\widetilde{\sigma}}{\sigma}$ & $\stackrel{a}{a}$ & $\begin{array}{l}\stackrel{+}{+} \\
\stackrel{+}{+} \\
\stackrel{0}{0}\end{array}$ & * \\
\hline & $\frac{\pi}{2}$ & 勇 & & 齐 & & U & & Z & & 昰 & & 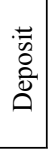 & & $\begin{array}{l}0 \\
\mathbb{0} \\
\tilde{0} \\
己 \\
0\end{array}$ & & $\begin{array}{l}\dot{j} \\
z \\
0 \\
0\end{array}$ & & 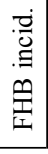 & & 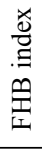 & \\
\hline
\end{tabular}




\section{Discussion}

The best fungicide coverage value of the front and rear wheat head sides measured on the WSPs was achieved with the use of AVI symmetric double flat fan air-injector nozzles and also with the use of alternately positioned FLOOD nozzles on the spray boom. Best coverage on the front head side with FLOOD nozzle was achieved due to higher water consumption 350 1/ha, while by other nozzles it was only 300 1/ha. Usually higher spray volume results in better coverage. The poorest head coverage resulted from the use of ID and IDK single vertical fan air-injector nozzles and the ST standard nozzle. Even the state-of-the-art AI asymmetric double flat fan air-injector nozzle did not achieve the expected fungicide coverage of wheat heads. Analysis of the quantity of deposit on the wheat head showed the largest quantity of tracer deposit on the wheat head with the use of AVI and FLOOD nozzles. The smallest quantity of tracer deposit occurred with ID, IDK, ST, TR and TT nozzles. These results are partially compatible with those of Mesterházy et al. (2011), who achieved the best wheat head coverage value $(37 \%)$ with the FLOOD nozzle and only $12 \%$ coverage with the XR standard nozzle. In our trial, the use of the FLOOD nozzle led to an average coverage (involving both trial years) of $26.5 \%$ of WSP, while the ST standard nozzle led to an average coverage of $11.9 \%$. Our results differ from the results of Vajs et al. (2008), who achieved the best wheat head coverage value with the use of VMD standard nozzles with a $170 \mu \mathrm{m}$ VMD. On the other hand, the poorest coverage value in their trial was achieved with the use of IDK single fan air-injector nozzles, which is compatible with our results. In terms of the fungicide deposit on the wheat head, we presume that the use of a single spray vertical to the ground and the use of air-injector and standard nozzles result in poorer coverage of the wheat head in comparison to the other nozzles used in the trial.

We were also interested in the fungicide mixture coverage of the lower-lying leaves, since these also need to be protected. On the flag leaf (1), the use of the ST standard nozzle with a single vertical fan resulted in better coverage than the use of other nozzles. The use of the ST nozzle also achieved good fungicide coverage values on the second and third leaves. Large coverage of the $2^{\text {nd }}, 3^{\text {rd }}$ and $4^{\text {th }}$ leaves was also achieved with the TR standard hollow cone nozzle. As expected, large coverage value on the ground was achieved with the use of ID and IDK single vertical fan air-injector nozzles and the use of the TTJ nozzle. The results show the lack of a universal nozzle that would enable good fungicide coverage of both wheat head and lower-lying leaves. On leaves only Septoria spp. was present in minority but under the economic threshold.

The highest FHB incidence occurred on the unsprayed control. The results of the FHB index show that the use of the IDK nozzle resulted in a higher FHB index in comparison to other nozzle types. These results show that the poorer fungicide deposit on the wheat head with the IDK nozzle is connected with a higher FHB index than with nozzles that offer good wheat head coverage, such as AI, AVI, FLOOD and SPEED nozzles. We would have to continue the study in conditions with higher level of infection to get clearer results. Despite the wheat head infections, DON content was very low $(<50 \mu \mathrm{g} / \mathrm{kg})$, because of low level of infection in both trial years. 
The yields achieved with the IDK and TD nozzle were higher than with the use of the TD nozzle compared with the yield from untreated control. Based on these results, we cannot claim that better wheat head fungicide coverage achieved with the use of a particular nozzle leads to a higher grain yield. In comparison with the unsprayed control, the grain yields on the plots sprayed with different nozzles were, on average, up to $17.5 \%$ higher. Vajs et al. (2008) did not find any significant differences in the grain yield among the different nozzles after spraying with Prosaro fungicide. The authors used 5 different nozzles, with only the IDK nozzle common to both their and our trials. Our results are compatible with those of Blandino et al. (2011) who, on a three-year average, managed to produce a $26 \%$ higher grain yield on sprayed plots in comparison to the unsprayed control. Miedaner (2012) states that in years with stronger FHB infections of wheat, the yield on the unsprayed control may even be lower by 30\%. Before him, Mesterházy et al. (2003) reported that stronger FHB infections of wheat might lower the grain yield even by $60 \%$.

No statistically significant differences were found in the thousand grain weight, in hectolitre weight, in falling number, in sedimentation and in protein content among the treatments, that is why correlation matrix between variables in the trial was calculated. In our trial negative correlation was found between yield and hectolitre weight and between yield and protein content. However positive correlation appeared between yield and falling number, and between yield and sedimentation. These results show that grain quality parameters are not dependent so much on spraying technology with different nozzle types, but more on other factors as cultivar characteristics, etc. Negative correlations were found between yield and DON content, and between yield and FHB index as reported by Blandino et al. (2011), Mesterházy et al. (2003) and Miedaner (2012). Blandino et al. (2011) determined that, on a three-year average, the thousand grain weight on plots sprayed against FHB was greater by $5.5 \%$ in comparison with the unsprayed control. In our trial negative correlation was found between the thousang grain weight and FHB incidence. There is a dearth of similar research performed with different nozzles. Blandino et al. (2011) determined that, on sprayed plots, the hectolitre weight of the grains is greater by $2.1 \%$ in comparison to the unsprayed control. We found positive correlations between hectolitre weight and protein content, between hectolitre weight and fungicide coverage, between hectolitre weight and deposit, and between hectolitre weight and FHB index. On the contrary, negative correlation was determined between hectolitre weight and falling number. Miedaner (2012) states that stronger FHB infections of wheat can lower the quality of flour since they cause the proteins and starch in the grains to decompose. He also states a decrease in the falling number. His results are not directly comparable because in our trial there was low infection level. However negative correlation was determined between falling number and FHB incidence, between falling number and FHB index, and between falling number and fungicide coverage. Blandino et al. (2006) also did not determine any connection between the bread making quality and the level of FHB. The results in relation to the protein content in the grains were similar to those with the sedimentation index. These results are consistent with expectations that an increase in the protein content of the grains causes an increase in the sedimentation index. Breitened- 
er and Radauer (2004) reported about increased protein content in infected grains with Fusarium. Comparing to their results positive correlation was determined between protein content and DON content in our trial. With stronger FHB infections, these results might have been different. Between DON content and FHB incidence positive correlation appeared, which was also confirmed in studies of Blandino et al. (2006) and Palazzini et al. (2015).

Further studies are necessary to evaluate the effect of nozzle type on head coverage, DON content and yield parameters with different winter wheat cultivars and in different conditions. As literature data show different efficacy data for different nozzles, further nozzle types should be tested to find better solutions for FHB control in the future.

\section{References}

Ages 2013. Austrian list of described cultivars. Österreichische Agentur fur Gesundheit und Ernährungssicherheit $\mathrm{GmbH}$, Vienna, Austria. 131 p. (in German)

Blandino, M., Minelli, L., Reyneri, A. 2006. Strategies fort the chemical control of Fusarium

head blight: effect on yield, alveographyc parameters and deoxynivalenol contamination in winter wheat grain. Eur. J. Agron. 25:193-201.

Blandino, M., Pascale, M., Haidukowski, M., Reyneri, A. 2011. Influence of agronomic conditions on the efficacy of different fungicides applied to wheat at heading: effect of flag senescence, Fusarium head blight attack, grain yield and deoxynivalenol contamination. Italian J. of Agron. 6:204-211.

Breiteneder, H., Radauer, C. 2004. A classification of plant food allergens. J. of Allergy and Clinical Immunology 113:821-830.

EPPO 1997. Guidelines for the efficacy evaluation of plant protection products. Vol. 2 fungicides and bactericides. European and Mediterranean Plant Protection Organization, Paris, France.

Halley S., Pederson J., McMullen M., Lukach J. 1999. Sprayer modifications for enhanced control of Fusarium head blight with fungicides. In: Proc. National Fusarium Head Blight Forum, Sioux Fall, SD, USA, pp. $50-52$.

Hollingsworth, C.R., Motteberg, C.D., Thompson,W.G. 2006. Assessing fungicide efficacies for the management of Fusarium head blight on spring wheat and barley. Plant Health Progress pp. 1-6.

https://www.plantmanagementnetwork.org/pub/php/research/2006/fusarium/

Lechoczki-Krsjak, S., Tóth, B., Kotai, C., Martonosi, I., Farady, L., Kondrak, L., Szabo-Hever, A., Mesterházy, A. 2008. Chemical control of FHB in wheat with different nozzle types and fungicides. Cereal Res. Commun. 36:677-681.

Marshall, D.J., Robinson, T.H., Scott, T. 2000. The effects of forward speed, spray quality and nozzle types on the deposition and biological performance of strobilurin fungicide. Asp. Appl. Biol. 57:235-242.

Mesterházy, Á., Bartok ,T., Lamper, C. 2003. Influence of wheat cultivar, species of Fusarium, and isolate aggressiveness on the efficacy of fungicides for control of Fusarium head blight. Plant Disease 87:1107-1115.

Mesterházy, Á., Tóth, B., Varga, M., Bartók, T., Szabó-Hevér, Á., Farády, L., Lehoczki- Krsjak, S. 2011. Role of fungicides, application of nozzle types, and the resistance level of wheat varieties in the control of Fusarium head blight and deoxynivalenol. Toxins 3:1453-1483.

Miedaner, T. 2012. Mykotoksine in Weizen und Mais. Fusarien erfolgreich vorbeugen (Mycotoxins in Wheat and Maize. Efficient Fusarium Control). DLG Verlag GmbH, Frankfurt am Main, Germany, 88 p. (in German).

Palazzini, J., Fumero, V., Yerkovich, N., Barros, G., Cuniberti, M., Chulze, S. 2015. Correlation between Fusarium graminearum and deoxynivalenol during the 2012/13 wheat fusarium head blight outbreak in Argentina. Cereal Res. Commun. 43:627-637. 
Parkin, C.S., Miller, P.C.H., Powell, E.S., Orson, J.H., Gill, J., Magan, N., Aldred, D. 2006. Improving the deposition and coverage of fungicides on ears to control Fusarium ear blight and reduce mycotoxin contamination of grain. Project Report No. 383. HGCA. London, UK. 33 p.

Ransom, J.K., McMullen, M.V. 2008. Yield and disease control on hard winter wheat cultivars with foliar fungicides. Agron. J. 100:1130-1137.

Vajs, S., Leskošek, G., Simončič, A., Lešnik, M. 2008. Comparison of the effectiveness of standard and driftreducing nozzles for control of some winter wheat diseases. J. of Plant Diseases and Protection 115:23-31. 